\title{
Evaluation of thrombotic thrombocytopenic purpura cases: A single-center experience
}

\author{
Trombotik trombositopenik purpura olgularının değerlendirmesi: Tek merkez deneyimi
}

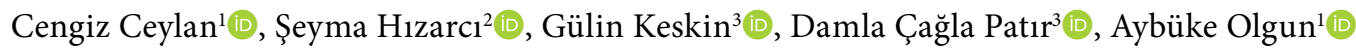 \\ ${ }^{1}$ Department of Hematology, University of Health Sciences, İzmir Tepecik Training and Research Hospital, İzmir, Turkey \\ ${ }^{2}$ Therapeutic Apheresis Unit, University of Health Sciences, İzmir Tepecik Training and Research Hospital, İzmir, Turkey \\ ${ }^{3}$ Department of Internal Medicine, University of Health Sciences, İzmir Tepecik Training and Research Hospital, İzmir, Turkey
}

\begin{abstract}
Objectives: In this study, we aimed to analyze the laboratory data of patients with idiopathic thrombotic thrombocytopenic purpura (TTP).

Patients and methods: A total of 20 patients (7 males, 13 females; median age 42.5 years, range 20 to 75 years) diagnosed with idiopathic TTP were retrospectively evaluated. Age, sex, median plasmapheresis count, LDH, platelet count, hemoglobin, hematocrit, indirect bilirubin levels, and treatment responses of the patients were assessed. Groups were formed according to plasmic score.

Results: Lactate dehydrogenase (LDH) levels before and after plasmapheresis, on day 1, 3, and 7, total and indirect bilirubin levels, creatinine, AST/ALT, hemoglobin, leukocyte values, and platelet counts were compared. The median LDH levels of patients regressed to normal in an average of three days (range: 1-19). Mean platelet count was $47,100 / \mu \mathrm{L}$ at admission. Platelet count returned to normal in a median of 7 (3-32) days. The median number of plasmapheresis procedures was 8.5 (5-58). All patients underwent prednisolone treatment. Three patients died, in which one had severe neurological involvement. Mortality rate was $15 \%$.

Conclusion: In the treatment of TTP, monitoring of LDH, platelet count and bilurubin values is important in evaluating the treatment response of plasmapheresis process. Further studies involving patient data are needed for the plasmic score used to assess severe idiopathic ADAMTS13 deficiency. Keywords: Idiopathic thrombotic thrombocytopenic purpura, plasmapheresis, plasmic score.
\end{abstract}

$\ddot{o z z}$

Amaç: Bu çalışmada idiyopatik trombotik trombositopenik purpura (TTP) hastalarının laboratuvar verileri değerlendirildi.

Hastalar ve yöntemler: İdiyopatik TTP tanısı konulan 20 hasta (7 erkek, 13 kadın; ortanca yaş 42,5 yıl; dağılım 20-75 yıl) retrospektif olarak değerlendirildi. Hastaların yaş, cinsiyet, ortanca plazmaferez sayısı, laktat dehidrogenaz (LDH), trombosit sayısı, hemoglobin, hematokrit, indirekt bilirubin düzeyleri ve tedavi yanıtları değerlendirildi. Gruplar plasmic skora göre oluşturuldu.

Bulgular: Hastaların plazmaferez işlemi öncesi ve sonrası 1. gün, 3. gün ve 7. gün LDH, total ve indirekt bilirubin düzeyi, kreatinin, AST/ALT, hemoglobin, lökosit değerleri ve trombosit sayıları karşılaştıııldı. Hastaların işlem öncesi yüksek olan ortanca LDH değeri, ortalama üç günde (1-19 gün) normale geriledi. Hastaların başvuru anında trombosit değerleri ortalama $47100 / \mu \mathrm{L}$ idi. Hastaların tedavi sonrası trombosit değerleri ortanca yedi günde (3-32 gün) normale döndü. Plazmaferez işlemi sayısı ortanca 8.5 (5-58) idi. Tüm hastalara prednizolon tedavisi verildi. Nörolojik tutulum ağır olan bir hastanın yanı sıra, toplamda üç hasta kaybedildi. Mortalite oranı \%15 idi.

Sonuç: Trombotik trombositopenik purpura tedavisinde plazmaferez işleminin tedavi yanıtını değerlendirmede erken dönemde LDH, trombosit sayısı ve bilurubin değerlerinin takibi önemli olmaktadır. Ciddi idyopatik ADAMTS13 eksikliğini değerlendirmek için kullanılan plasmic skor için daha çok hasta verilerini içeren çalışmalara gereksinim mevcuttur.

Anahtar sözcükler: İdiyopatik trombotik trombositopenik purpura, plazmaferez, plasmic skor.

Thrombotic microangiopathic hemolytic anemia was first described under thrombotic thrombocytopenic purpura by Symmers

in 1952. ${ }^{[1]}$ Thrombotic microangiopathies
are characterized by thrombosis in
microvasculature involving various organs.

Received: July 16, 2019 Accepted: August 08, 2019 Published online: October 31, 2019

Correspondence: Damla Çağla Patır. Sağlık Bilimleri Üniversitesi, İzmir Tepecik SUAM, İç Hastalıkları Kliniği, 35180 Yenişehir, Konak, İzmir, Türkiye. Tel: +90539 - 2730592 e-mail: damlapatir@yahoo.com 
Thrombotic thrombocytopenic purpura (TTP) and atypical hemolytic uremic syndrome (aHUS) are classic examples. Microangiopathic changes may also be caused by disseminated intravascular coagulation, autoimmune diseases, neoplasms, and infections. ${ }^{[2]}$ With accumulation of thrombosis in microvasculature, these diseases are characterized by thrombocytopenia, neurologic symptoms, impaired renal functions, and direct Coombs negative microangiopathic hemolytic anemia as a result of erythrocyte damage in microcirculation. ${ }^{[3]}$

Thrombotic thrombocytopenic purpura incidence is reportedly 2-4 cases per million per year. ${ }^{[4]}$ Despite ADAMTS13 enzyme deficiency of $<10 \%$ as a requirement for TTP diagnosis, this may be impossible to test in emergency conditions. In fact, commercial kits may show inconsistency in up to $12 \%$ of patients. ${ }^{[5,6]}$ The disease may be congenital or acquired depending on ADAMTS13 activity and inhibitor levels.

Thrombotic thrombocytopenic purpura primarily affects the central nervous system and gastrointestinal system. Although renal involvement is shown in renal biopsies, clinical acute renal failure is limited. While acute renal failure is forefront in hemolytic uremic syndrome, classic TTP mainly manifests neurological symptoms. Because mortality rate is $95 \%$ when untreated, most cases should be immediately assessed to initiate plasmapheresis. Intense plasma exchange in recent years has lowered acute mortality of TTP to less than $25 \% .{ }^{[7]}$

This retrospective study investigates the effect of demographics and plasmapheresis on biochemical parameters in patients diagnosed with idiopathic TTP.

\section{PATIENTS AND METHODS}

In this study, patients admitted to the İzmir Tepecik Training and Research Hospital Hematology Clinic diagnosed with microangiopathic hemolytic anemia between 2014-2017 and who had hemolysis parameters tested, underwent treatment and follow-up, had ADAMTS13 activity tested at initial diagnosis, and underwent immediate plasmapheresis (PEX) were included in the study. All patients with drug-associated microangiopathic hemolytic anemia, rheumatic disease, solid tumor, and infection were excluded from the study. Twenty patients ( 7 males, 13 females; median age 42.5 years; range, 20 to 75 years) followed up with diagnosis of TTP were retrospectively evaluated. Patients with ADAMTS-13 activity of less than $10 \%$ were followed up with TTP diagnosis. ADAMTS-13 activity could not be assessed in some patients due to urgent plasmapheresis, but were considered TTP since plasmapheresis achieved clinical recovery. Recommended replacement dosage (1-1.5× plasma volume) was administered in every plasmapheresis procedure. Standard prednisolone treatment was also initiated. Patients with platelet count $>150,000$ for two consecutive days and normal lactate dehydrogenase (LDH) levels were considered responsive to treatment and plasmapheresis treatment was discontinued.

The study protocol was approved by the İzmir Tepecik Training and Research Hospital Ethics Committee. Informed written consent was obtained from each patient. The study was conducted in accordance with the principles of the Declaration of Helsinki.

\section{Statistical analysis}

Statistical analysis was performed using the IBM SPSS for Windows version 20.0 software (IBM Corp., Armonk, NY, USA). The nonparametric test Wilcoxon test was used to assess LDH and platelet analyses for assessment of data without normal distribution. Descriptive statistics were expressed as frequency and median (minimum-maximum). The value of $\mathrm{p}<0.05$ was considered statistically significant.

\section{RESULTS}

Lactate dehydrogenase, total and indirect bilirubin, creatinine, AST/ALT, hemoglobin, hematocrit, leukocyte and platelet values of before plasmapheresis, and one, three, and seven days after plasmapheresis were compared (Table 1). Three patients died during the treatment period. Median plasmapheresis count was 8.5 (5-85); while LDH returned to normal in median three days (range: 1-19); platelet count regressed to normal in median seven days (range, 3-32) and indirect bilirubin similarly regressed to normal in median of three days (range, 1-8) (Table 2). Median LDH value was $702.5 \mathrm{U} / \mathrm{L}$ on day one which decreased to median of $244 \mathrm{U} / \mathrm{L}$ on day seven. Hemoglobin was median 
Table 1. Median values of data before and during plasmapheresis

\begin{tabular}{|c|c|c|c|c|c|c|c|c|}
\hline & \multicolumn{2}{|c|}{ Before plasmapheresis } & \multicolumn{2}{|c|}{ Day 1} & \multicolumn{2}{|c|}{ Day 3} & \multicolumn{2}{|c|}{ Day 7} \\
\hline & Median & Min-Max & Median & Min-Max & Median & Min-Max & Median & Min-Max \\
\hline Lactate dehydrogenase (U/L) & 702.5 & $200-2,570$ & 464 & $208-1,300$ & 267 & $162-1,604$ & 244 & $100-633$ \\
\hline Hemoglobin (g/dL) & 9.65 & $5.8-14.9$ & 8.75 & $6.0-15.1$ & 8.15 & $6.3-10.2$ & 9.6 & $6.6-11.3$ \\
\hline Platelet $(/ \mu \mathrm{L})$ & 33 & $7-183$ & 30 & $6-149$ & 68.5 & $8-352$ & 151 & $7-495$ \\
\hline Hematocrit (\%) & 27.5 & $17-44$ & 25.9 & $18-45$ & 26.8 & $20-31$ & 28.7 & $18-34$ \\
\hline Creatinine (mg/dL) & 1.00 & $0.6-11.5$ & 1.00 & $0.6-11$ & 0.9 & $0.7-7.5$ & 0.9 & $0.6-5.9$ \\
\hline Indirect bilirubin (g/dL) & 1.26 & $0.09-3.44$ & 0.87 & $0.08-3.63$ & 0.48 & $0.03-2.22$ & 0.95 & $0.32-2.39$ \\
\hline
\end{tabular}

Table 2. Patient data

\begin{tabular}{|c|c|c|c|c|}
\hline & $\mathrm{n}$ & $\%$ & Median & Min-Max \\
\hline Age (year) & & & 42.5 & $20-75$ \\
\hline Number of exitus patients & 3 & 15 & & \\
\hline $\begin{array}{l}\text { Gender } \\
\text { Male } \\
\text { Female }\end{array}$ & $\begin{array}{c}7 \\
13\end{array}$ & & & \\
\hline Median plasmapheresis count & 8.5 & & & $5-85$ \\
\hline Number of days until normal lactate dehydrogenase & 3 & & & $1-19$ \\
\hline Number of days until normal platelet count & 7 & & & 3-32 \\
\hline Number of days until normal bilirubin & 3 & & & $1-8$ \\
\hline
\end{tabular}

Min: Minimum; Max: Maximum.

$9.65 \mathrm{~g} / \mathrm{dL}$ on day one and 9.6 (range, 6.6-11.3) on day seven, while initial median platelet count was $33,000 / \mu \mathrm{L}, 68,000 / \mu \mathrm{L}$ on day three, and $151,000 / \mu \mathrm{L}$ on day seven. Median platelet count was not statistically significant on day one, but there was significant increase between day three and day seven (Figure 1). Plasmic score evaluation was performed for 20 patients. ${ }^{[8]}$ Seven patients (35\%) had low score, 10 patients (50\%) moderate score, and three patients had high plasmic score (Table 3). Of the three patients who died, one had plasmic score of seven, the other two patients had plasmic scores of 5 and 4 . The plasmic scores of the 20 patients are presented in Table 3 .

\section{DISCUSSION}

Thrombotic thrombocytopenic purpura has an incidence of 2-6 per million and results in $100 \%$ mortality if left untreated. The basic treatment approach of TTP is 1-1.5× plasma volume/day plasmapheresis, $1 \mathrm{mg} / \mathrm{kg} /$ day prednisolone, and if there is more than 12 hours delay to initiation of plasma exchange, plasma infusion (20-40 mL/kg/day), and $80 \mathrm{mg} /$ day aspirin in select patients with platelet count over 50,000. Some studies report mortality of $10-20 \%$ despite plasmapheresis. ${ }^{[9,10]}$ In this study, mortality was $15 \%$ and consistent with the literature. According to data from England, France, and the United States, TTP mostly affects

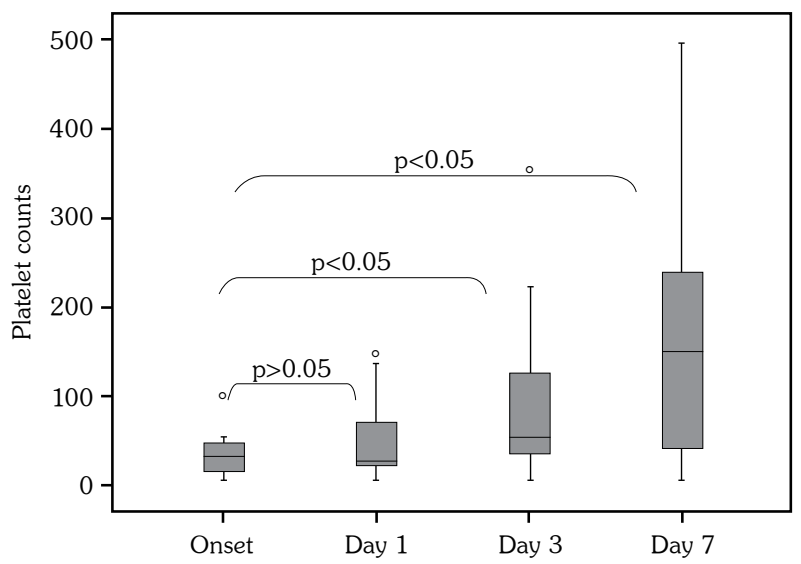

Figure 1. Platelet counts before and during plasmapheresis. 


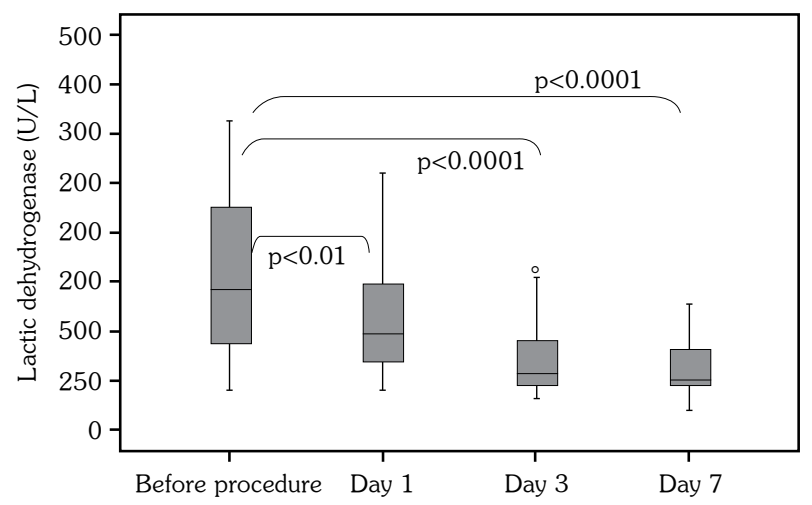

Figure 2. Lactate dehydrogenase levels before and during plasmapheresis.

Table 3. Plasmic score distribution of 20 patients

\begin{tabular}{lcc}
\hline Plasmic score & $\mathrm{n}$ & $\%$ \\
\hline Low (0-4) & 7 & 35 \\
Moderate (5) & 10 & 50 \\
High (6-7) & 3 & 15 \\
\hline
\end{tabular}

women between age 40-50, ${ }^{[9,11]}$ consistent with our findings. Median age of male patients was 59 years (range, 31-75). Old data reported renal involvement in TTP was 18\%, although newer research reports this rate ranges from $10-76 \% .^{[12]}$ In our study, 10 of the 20 patients (50\%) had initial renal involvement. Four patients had creatinine level above $2.5 \mathrm{mg} / \mathrm{dL}$. Thrombocytopenia and microangiopathic hemolytic anemia are initial findings of TTP. Platelet count $<20 \times 10^{9} / \mathrm{L}$, Hemoglobin $<9 \mathrm{~g} / \mathrm{dL}$, Bilirubin $>2 \mathrm{mg} / \mathrm{dL}$, and LDH may be elevated by up to four times. In our patient group, median platelet count was $33 \times 10^{9} / \mathrm{L}$. Five patients (25\%) had platelet count below $20 \times 10^{9} / \mathrm{L}$. Median platelet count was $30 \times 10^{9} / \mathrm{L}$ on day one, $68.2 \times 10^{9} / \mathrm{L}$ on day three, and returned to normal in median of seven days. Platelet count, hemoglobin, LDH, and schistocytes in peripheral smear were considered reliable parameters in monitoring response of patients who underwent plasmapheresis. Platelet count began to increase on day three of plasmapheresis and was consistent with treatment response. Patients were reassessed with peripheral smear, although we could not obtain this data from records. Not all studies consider LDH level a helpful parameter, ${ }^{[13]}$ while red cell distribution width (RDW) may be an important parameter for monitoring schistocytes. ${ }^{[14]}$ In our study, $\mathrm{LDH}$ values were prone to decrease on day one, which was inconsistent with the literature, and appeared helpful in monitoring plasmapheresis treatment (Figure 2). Time until LDH regressed to normal was relatively shorter compared to platelet count and occurred in a median of three days. We believe $\mathrm{LDH}$ value is an important indicator of plasmapheresis response in the early term. Median plasmapheresis time was 8.5 days (range, 5-85); Swart et al. ${ }^{[15]}$ reported median plasmapheresis time of 10.0 .

Seven separate parameters including plasmic score, ${ }^{[8]}$ platelet count, degree of hemolysis, presence of cancer, lack of transplantation, Mean corpuscular volume (MCV) value, international normalized ratio (INR), and creatinine allow evaluation of prognosis in patients with severe ADAMTS13 deficiency. In this study, one of the three patients with plasmic score of 6-7 died, with mortality rate as 33\% (Table 3). The other two exitus patients had plasmic score of 5 . The low number of patients was a limitation on evaluation of plasmic score.

Thrombotic thrombocytopenic purpura is a rare disease that causes thrombotic microangiopathy. Early diagnosis and effective treatment of thrombotic thrombocytopenic purpura significantly reduces mortality rates. The common outcome of ours and other studies suggest that plasmapheresis should be initiated as soon as possible in suspected TTP or when TTP cannot be ruled out. Furthermore, various scoring systems may be early predictors of prognosis. Without waiting for ADAMTS13 results, evaluating patients according to clinical and laboratory data is important. We also determined that decreased $\mathrm{LDH}$ in the early term is also a finding that can be used to assess response to treatment in patients undergoing plasmapheresis. As plasmic score was unevaluated in our patients due to low patient sample, further research should be conducted on a broader scale.

\section{Declaration of conflicting interests}

The authors declared no conflicts of interest with respect to the authorship and/or publication of this article.

\section{Funding}

The authors received no financial support for the research and/or authorship of this article. 


\section{REFERENCES}

1. Symmers WS. Thrombotic microangiopathic haemolytic anaemia (thrombotic microangiopathy). $\mathrm{Br}$ Med J 1952;2:897-903.

2. Tekgündüz E, Yllmaz M, Erkurt MA, Kiki I, Kaya $\mathrm{AH}$, Kaynar L, et al. A multicenter experience of thrombotic microangiopathies in Turkey: The Turkish Hematology Research and Education Group (ThREG)TMA01 study. Transfus Apher Sci 2018;57:27-30.

3. Åkesson A, Zetterberg E, Klintman J. At the cross section of thrombotic microangiopathy and atypical hemolytic uremic syndrome: a narrative review of differential diagnostics and a problematization of nomenclature. Ther Apher Dial 2017;21:304-19.

4. Legrand M, Max A, Peigne V, Mariotte E, Canet E, Debrumetz A, et al. Survival in neutropenic patients with severe sepsis or septic shock. Crit Care Med 2012;40:43-9.

5. Joly BS, Coppo P, Veyradier A. Thrombotic thrombocytopenic purpura. Blood 2017;129:283646.

6. Zheng XL, Sadler JE. Pathogenesis of thrombotic microangiopathies. Annu Rev Pathol 2008;3:249-77.

7. George JN. How I treat patients with thrombotic thrombocytopenic purpura: 2010. Blood 2010;116:4060-9.

8. Bendapudi PK, Hurwitz S, Fry A, Marques MB, Waldo SW, Li A, et al. Derivation and external validation of the PLASMIC score for rapid assessment of adults with thrombotic microangiopathies: a cohort study. Lancet Haematol 2017;4:e157-e64.

9. Scully M, Yarranton H, Liesner R, Cavenagh J,
Hunt B, Benjamin S, et al. Regional UK TTP registry: correlation with laboratory ADAMTS 13 analysis and clinical features. Br J Haematol 2008;142:819-26.

10. Kremer Hovinga JA, Vesely SK, Terrell DR, Lämmle B, George JN. Survival and relapse in patients with thrombotic thrombocytopenic purpura. Blood 2010;115:1500-11.

11. Mariotte E, Azoulay E, Galicier L, Rondeau E, Zouiti F, Boisseau P, et al. Epidemiology and pathophysiology of adulthood-onset thrombotic microangiopathy with severe ADAMTS13 deficiency (thrombotic thrombocytopenic purpura): a crosssectional analysis of the French national registry for thrombotic microangiopathy. Lancet Haematol 2016;3:e237-e45.

12. Blombery P, Kivivali L, Pepperell D, McQuilten Z, Engelbrecht S, Polizzotto MN, et al. Diagnosis and management of thrombotic thrombocytopenic purpura (TTP) in Australia: findings from the first 5 years of the Australian TTP/thrombotic microangiopathy registry. Intern Med J 2016;46:71-9.

13. Cohen JA, Brecher ME, Bandarenko N. Cellular source of serum lactate dehydrogenase elevation in patients with thrombotic thrombocytopenic purpura. J Clin Apher 1998;13:16-9.

14. Yoo JH, Lee J, Roh KH, Kim HO, Song JW, Choi $\mathrm{JR}$, et al. Rapid identification of thrombocytopeniaassociated multiple organ failure using red blood cell parameters and a volume/hemoglobin concentration cytogram. Yonsei Med J 2011;52:845-50.

15. Swart L, Schapkaitz E, Mahlangu JN. Thrombotic thrombocytopenic purpura: A 5-year tertiary care centre experience. J Clin Apher 2019;34:44-50. 